\title{
DC Fast-Charging Stations for EVs Controlled by a Local Battery Storage in Low Voltage Grids
}

\author{
Gjelaj, Marjan; Træholt, Chresten; Hashemi Toghroljerdi, Seyedmostafa; Andersen, Peter Bach
}

Published in:

Proceedings of 12th IEEE Power and Energy Society PowerTech Conference

Link to article, DOI:

10.1109/PTC.2017.7980985

Publication date:

2017

Document Version

Peer reviewed version

Link back to DTU Orbit

Citation (APA):

Gjelaj, M., Træholt, C., Hashemi Toghroljerdi, S., \& Andersen, P. B. (2017). DC Fast-Charging Stations for EVs Controlled by a Local Battery Storage in Low Voltage Grids. In Proceedings of 12th IEEE Power and Energy Society PowerTech Conference IEEE. https://doi.org/10.1109/PTC.2017.7980985

\section{General rights}

Copyright and moral rights for the publications made accessible in the public portal are retained by the authors and/or other copyright owners and it is a condition of accessing publications that users recognise and abide by the legal requirements associated with these rights.

- Users may download and print one copy of any publication from the public portal for the purpose of private study or research.

- You may not further distribute the material or use it for any profit-making activity or commercial gain

- You may freely distribute the URL identifying the publication in the public portal 


\title{
DC Fast-Charging Stations for EVs Controlled by a Local Battery Storage in Low Voltage Grids
}

\author{
Marjan Gjelaj, Chresten Træholt, Seyedmostafa Hashemi, Peter Bach Andersen \\ EVLabDK-CEE Department of Electrical Engineering \\ Technical University of Denmark - Copenhagen, Denmark \\ Email: margje@elektro.dtu.dk, ctr@elektro.dtu.dk,shtog@elektro.dtu.dk,pba@elektro.dtu.dk
}

\begin{abstract}
Electric Vehicles (EVs) are representing a great opportunity for major car manufacturers to invest resources in new technologies in order to support sustainable transportation and the reduction of $\mathrm{CO}_{2}$ emissions, in particular in the metropolitan areas. In recent years, the increasing penetration of EVs and their charging systems are going through a series of changes. This paper addresses the design of a new DC Fast Charging Station (DCFCS) for EVs coupled with a local Battery Energy Storage (BES) by using the IEC 15118, which provides a communication interface among different actors. DCFCS is equipped with a bidirectional AC/DC converter for feeding power back to the grid, two lithium batteries and a DC/DC converter. The proposed solution decreases the charging time of EVs and facilitates the integration of fast chargers in existing low voltage (LV) grids. The charging station can also be used as a multifunctional grid-utility for ancillary services such as primary frequency control, load levelling and congestion management.
\end{abstract}

Index Terms - Coordinated control, DC fast charging, battery energy storage, electric vehicle

\section{INTRODUCTION}

In recent years, the large-scale electrification of the transport sector has become a major field of research. The concept of the DC fast charging station is very important in terms of investigating possible solutions to manage and control the integration of numerous electric vehicles (EVs) in sustainable cities, especially as far as long-distance travel is concerned [1]. Many factors are contributing to the spread of electric transportation such as the high levels of motor vehicle pollution in many cities. In addition, the costs of electrical batteries are dropping to affordable levels with reasonable lifetimes and reliability [2]. Nevertheless, one main reason that prevents part of the new potential customers to opt for EVs is the longer charging time compared to gas fueled vehicles. So far, the fast charging station has met implementation difficulties in the major European cities, because its progress poses demanding requirements in terms of EV battery and issues related to the impact in low voltage (LV) grids [3]. Currently, the delivered power is between $7 \mathrm{~kW}$ and $43 \mathrm{~kW}$ in
AC for public charging stations [4]. Such charging rate requires about 1 hour or 2 hours to store the energy needed to cover $110 \mathrm{~km}$ to $150 \mathrm{~km}$.

To address this issue, research is moving in various directions. New business models were proposed that envision physical swap of battery stacks at dedicated stations, as in [5]. However, this solution still brings along concerns about batteries ownership and stock management. Another alternative approach, known as fast charging (FC) is to increase the charging power with a dedicated connection to the medium voltage (MV) grid. Though already successfully implemented, manufacturers still show a conservative attitude when it comes to allowing batteries to be charged at higher power rates due to overheating issues and faster degradation of the battery. In addition, in LV grids system operators are concerned about increased losses as well as potential lines overloads and network congestion. Moreover, fast charging stations require higher connection fees to grid operators in order to offset the cost of larger transformers and electrical equipment. Some authors focused on innovative tariff systems that allow a more even profile of the aggregated charging demand during the day [6]. Another study proposed to use stationary electrical batteries as a buffer between the grid and the charging stations in order to reduce their peak consumption [7].

This study covers the latter approach for reducing the impact of FC stations on the grid and aims to address some of the shortfalls not yet investigated. In particular, we propose a novel design of a stationary twin battery energy system (BES) that physically decouples a DC fast charging station (DCFCS) from an LV distribution grid, as shown in Figure 1. The operation of such a system is based on successive switches of the BES connections that allow one of the batteries (BES2) to be charged from the grid while the other (BES1) is charging an $\mathrm{EV}$, as shown in Figure 2. The user that immediately followed would be served by BES2 that has just been charged. This method has the advantage of reducing the grid utility peak demand, connection costs and charging time. 
The rest of the manuscript is organized as follows. In Section II and III state of the art and the integration of fast charging in LV grids are presented, respectively. The description of the design and operation of the proposed charging station are given in Section IV and V, respectively. Results from simulated scenarios in terms of optimal control of batteries are presented in Section VI. Finally, in Section VII a discussion on the implications of the proposed system concerning its practical implementation and the needs for further investigation are provided.

\section{EVS CHARGING MODES: STATE OF THE ART}

According to the international standard IEC 61851 "electric vehicle conductive charging system," there are different charging modes classified as mode 1, 2, 3 and [4]. The part 1 and part 2 of the standard are applied to on-board and off-board equipment for charging EVs and providing electrical power for any additional services on the vehicles. One method for charging EVs is to connect the AC supply grid to an on-board charger. An alternative method for charging an $\mathrm{EV}$ is to use an off-board charger for delivering direct current for charging in a short period of time. The charging modes for EVs are the following: Charging mode1: connection of the EV to the AC with a supply grid not exceeding $16-\mathrm{A}$ and $11 \mathrm{~kW}$ and it is used at home. Charging mode 2: connection of the $\mathrm{EV}$ to the AC with a supply grid not exceeding $32-\mathrm{A}$ and $22 \mathrm{~kW}$. It is primarily used for dedicated private facilities. Charging Mode 3: permanently connected to the $\mathrm{AC}$ with a supply grid not exceeding $63-\mathrm{A}$ and $43 \mathrm{~kW}$. This charging mode is typical for public charging stations. Charging mode 4: the mode 4 has been implemented for off-board chargers in DC. The IEC 61851part 23 and 24 provide the general requirements for the control communication between a DCcharger and an EV, according to IEC 15118 [8]. The charging time at this moment in mode 4 is from 30 to 50 minutes to reach $80 \%$ of battery state of charge (SoC) with power from $50 \mathrm{~kW}$ up to $120 \mathrm{~kW}$.

TABLE I. PROFILE OF CHARGING CONDITIONS AND MODES

\begin{tabular}{|c|c|c|}
\hline Charging Mode & Max Current & Vehicle Battery Charger \\
\hline Mode 1 & 16 A & $4-8 \mathrm{~h}$ \\
\hline Mode 2 & 32 A & $2-4 \mathrm{~h}$ \\
\hline Mode 3 & $63 \mathrm{~A}$ & $1-2 \mathrm{~h}$ \\
\hline Mode 4 & $400 \mathrm{~A} \mathrm{DC}$ & $5-30 \mathrm{~min}$ \\
\hline
\end{tabular}

The IEC 62196 applies to plugs, socket-outlets and connectors which use conductive charging [9]. The standard allows to recharging in DC with $400 \mathrm{~A}$ and power from $50 \mathrm{~kW}$ up to $240 \mathrm{~kW}$ in Chademo and Combined Charging System (Combo). In most large cities a substantial part of the installed chargers use mode 2 and mode 3 , for the following reasons: low infrastructure costs, electrical grid, and international standards availability. Nowadays, the charging architecture in $\mathrm{AC}$ is robust but it has power limitations. Moreover, in mode 3 the charging rate to reach $80 \%$ of the EV battery with $22 \mathrm{~kW}$ takes approximately 1 hour with a vehicle of $20 \mathrm{kWh}$. Furthermore, this raises issues of space congestion of the public parking and in the future additional cost for the $\mathrm{EV}$ parking; furthermore, recharging in AC entails high conversion losses on the EV side. The efficiency of an onboard converter is around $85 \%$, and this represents an increasing energy demand from the EV in order to reach $80 \%$ of SoC. In addition, the low efficiency of the on-board charging is reflected on the total energy consumed, which adds additional costs on the users. An idea to solve this problem is to focus the attention on the mode 4: DC fast charging station and in particular their integration in the LV grid. State of the art at the moment is the following: $120 \mathrm{~kW}$ by Tesla connected in $\mathrm{MV}, 50 \mathrm{~kW}$ by $\mathrm{ABB}$ with combo in $\mathrm{LV}, 62.5 \mathrm{~kW}$ by Chademo system in LV. Mode 4 significantly reduces the charging time and the conversion losses on the EV side. These charging stations, especially in the range of $100 / 150 \mathrm{~kW}$, require a strong grid infrastructure with high investment cost. Such large installed capacities usually require MV, with an appropriate transformer. The transformer has high economic costs and space restrictions, especially if the installation takes place in the cities.

\section{INTEGRATION OF THE DC FAST CHARGING IN LV GRIDS}

The DCFCS in combination with the BES can represent a reliable solution to mitigate adverse effects on the grid, such as the reduction of the peak load demand from the EVs and benefits in terms of losses reduction from dispatching electric energy. It also makes a large contribution to the grid regulation and reinforcement [10]-[11]. Furthermore, the charger provides a number of advantages such as: power decoupling, increase of power levels and congestion management of interruptible loads. In addition, it can provide different ancillary services for supporting the power grid, such as primary frequency control or voltage control [12]-[13].

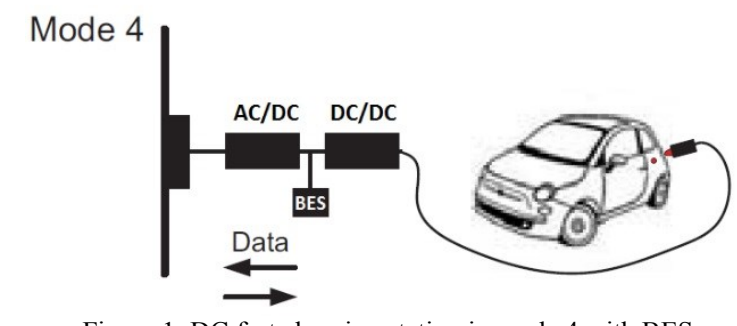

Figure 1. DC fast charging station in mode 4 with BES

The DCFCS represents an important element not only for recharging EVs but above all; we need innovative infrastructures for their integration with the smart grids, which interconnect the main grid with different kinds of renewable energy sources and stationary storage [14]. A very important aspect to take into account is the reduction of the cost of the lithium-ion battery; this could be transformed into an intelligent opportunity for integrating the penetration of EVs and the smart charging stations, which facilitates information and communication technologies. The cost of the Li-ion battery for electric vehicle (BEV) represents the $25 \%$ of the total cost of the EV. The annual cost reduction of BEVs has been estimated 
around $8 \%$ [2]. Consequently, this represents a chance to evaluate possible scenarios of the DCFCS in order to develop a smart charging station and control methods for these flexible loads [15].

In addition, data are collected and analyzed using the EVLabDK and EnergyLab Nordhavn, and a model for optimal operation of the BES in the distribution grid has been developed. The performance and interoperability of all those systems have been assessed from different perspectives, including communications management and functionalities of devices with the current technologies [16]. In particular, the evolution of power electronics interfaces, as well as battery storage, will be playing an important role. This DCFCS proposed is focused on a particular power electronic architecture composed by a bidirectional AC/DC converter, DC/DC converter and two BES. Through the combination of these components, the battery from the EV side is charged mainly from the first BES in agreement with the peak load demand of the EVs and their SoC.

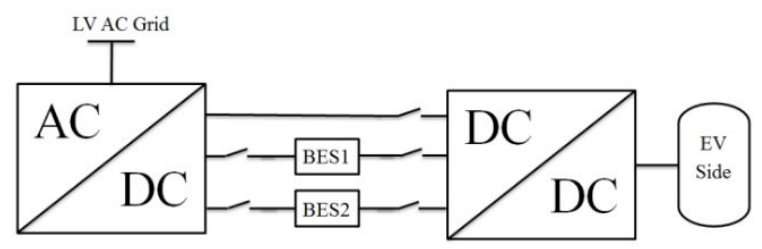

Figure 2. DC fast charging station in LV grids with BES

Through a proper sizing analysis the AC/DC will provide to recharge the second BES while the vehicle is in charge. In this case, with a full charge of the second BES, the DCFCS can give the opportunity to the next user to recharge the EV with the same charging rate of 10 minutes. The battery that was previously discharged is immediately going to be charged by the $\mathrm{AC} / \mathrm{DC}$ converter. If there is a possible congestion or problems with batteries, the EV is going to be charged directly by the grid through the AC/DC as shown in Figure 2.

\section{DESIGN THE OPTIMAL ARCHITECTURE OF THE DCFCS}

Batteries $\mathrm{BES}_{1}$ and $\mathrm{BES}_{2}$, converters $\mathrm{AC} / \mathrm{DC}$ and $\mathrm{DC} / \mathrm{DC}$ and the EV have been designed by using models available in Matlab/Simulink. For determining the optimal operation of the DCFCS, a large amount of data must be known, such as, such as the SoC of the battery, frequency of use and the objective charging time. The most important factors to take into account are the available power from the grid side and the battery charging process. The $\operatorname{SoC}(\mathrm{t})$ of the batteries (in \%) can be calculated as:

$$
\operatorname{SoC}(t)=\operatorname{SoC}_{0}+\frac{100}{\mathrm{Q}_{\text {Bat }}} \int_{\mathrm{t}_{0}}^{\mathrm{t}} \mathrm{I}_{\text {bat }}(\mathrm{t}) \mathrm{dt}
$$

where $\mathrm{Q}_{\mathrm{Bat}}$ is the maximum battery capacity, $\mathrm{I}_{\text {bat }}(\mathrm{t})$ is the battery current and $\mathrm{SoC}_{0}$ corresponds to the SoC of the battery at the beginning of the simulation $\left(t_{0}\right),(1)$. The local grid provides the battery-charging power (2), and it can be expressed as:

$$
\mathrm{P}_{\text {grid }}=\frac{1}{\eta_{\text {conv }}} \cdot \mathrm{i}_{\text {bat }} \cdot\left(\mathrm{u}_{0 \mathrm{C}} \cdot \mathrm{SoC}_{0}+\mathrm{i}_{\text {bat }} \cdot \sum \mathrm{R}_{\text {cell }}\right)
$$

The $\mathrm{i}_{\text {bat }}$ is the current given by the AD/DC converter, $u_{0 C}$ is open circuit voltage, the $R_{\text {cell }}$ is the resistive characteristics caused by the sum of the internal contact of individual cells at the end $\eta_{\text {conv }}$ represents the efficiency of the converter, and it is estimated at $95 \%$. The charging station will have one or more charging slots, and each of them can be connected in the LV grid with a minimum power of $22 \mathrm{~kW}$ required form the grid in AC. The load curve generation is deducted from the objective number of EV to be charged during the day. To make the power demand study more realistic the following steps are made:

1. The SoC of the EV battery has a range between $20 \%$ $50 \%$ with normally distributed of $35 \%$.

2. Battery capacity of the EV is between $5 \mathrm{kWh}-60 \mathrm{kWh}$ with normally distributed of $32.5 \mathrm{kWh}$.

3. The $u_{o c}$ the open circuit voltage has linear relationship to SoC.

4. The charging curves of the EVs are based on the objective charging time with $\mathrm{i}_{\text {ch }}$ constant.

The EV battery rated voltage $\mathrm{E}_{\mathrm{EV}, \mathrm{n}}$ changes according to the type of charging station. The DC off-board charger has $\mathrm{U}_{\mathrm{EV}, \mathrm{n}}=500 \mathrm{~V}$ with large battery pack around $23 \mathrm{kWh}$ up to $35 \mathrm{kWh}$. The SoC exchanged between the BES and the EV battery is from $20 \%$ to $80 \%$, and the resistance is considered with base value $\sum \mathrm{R}_{\text {cell }}(32.5 \mathrm{kWh})=98 \mathrm{~m} \Omega$ from the datasheet [17] and calculated in (3).

$$
\sum \mathrm{R}_{\text {cell }\left(\mathrm{E}_{\text {batt }}\right)}=\sum \mathrm{R}_{\text {cell }} \cdot(32.5 \mathrm{~kW} \cdot \mathrm{h}) \cdot \frac{32.5 \mathrm{~kW} \cdot \mathrm{h}}{\mathrm{E}_{\text {batt }}}
$$

The charging current $i_{c h}$ has been used to determine the objective charging time $t_{c h}$ and the $\mathrm{u}_{\mathrm{oc}}$ is considered to have linear relationship between $\mathrm{SoC}$ and $\mathrm{U}_{0}(4)$.

$$
\mathrm{u}_{\mathrm{oc}} \operatorname{SoC}(\%)=(0.8+0.2 \cdot \mathrm{SoC}) \cdot \mathrm{U}_{\mathrm{EV}, \mathrm{n}}
$$

The SoC is based on the coulomb count (5):

$\operatorname{SoC}(t)=\operatorname{SoC}_{i}+\frac{\Delta t}{Q_{b a t}} \cdot \sum_{\tau=0}^{t} i_{c h}, \tau$, with $Q_{b a t}=\frac{E_{\text {batt }}}{U_{E V, n}}$

$Q_{b a t}$ is called coulomb capacity of the battery and $\Delta \mathrm{t}$ is numerical integration time step. The charging process has been fixed when $\mathrm{SoC}=\mathrm{SoC}_{80 \%}$.

The battery terminal voltage is a sum of $u_{o c}$ and it drops across the internal resistance, calculated in (6):

$$
\mathrm{u}_{\mathrm{EV}}(\mathrm{t})=\mathrm{u}_{\mathrm{oc}}(\mathrm{SoC})+\mathrm{i}_{\mathrm{ch}} \cdot \sum \mathrm{R}_{\text {cell }}
$$

The power absorbed by the EV is calculated in (7):

$$
\mathrm{P}_{\mathrm{EV}}(\mathrm{t})=\mathrm{u}_{\mathrm{EV}}(\mathrm{t}) \cdot \mathrm{i}_{\mathrm{ch}}(\mathrm{t})
$$
(8):

The size of each BES can be calculated with the expression 


$$
\mathrm{BES}_{1}=\mathrm{BES}_{2}=0.35 \cdot 32.5 \mathrm{kWh}=11.4 \mathrm{kWh}
$$

Each BES has been oversized of $14.25 \mathrm{kWh}$ because it cannot exceeding $25 \% \mathrm{SoC}$ (8). The case study has used an $\mathrm{AD} / \mathrm{DC}$ converter of $50 \mathrm{~kW}$ and according to the discharging rate of $5 \mathrm{C}$ has been chosen a DC/DC converter of $70 \mathrm{~kW}$.

\section{DCFCS MODELLING AND CONTROL}

The main objective of the DCFCS is to control the power flow between the converters and the batteries $\mathrm{BES}_{1}, \mathrm{BES}_{2}$. The SOCs of the batteries, $\mathrm{BES}_{\mathrm{SoC} 1}$ and $\mathrm{BES}_{\mathrm{SoC} 2}$ are determined by measuring the voltage on the battery terminals $\mathrm{V}_{\mathrm{BES}}$ as shown in Figure 3. Furthermore, Figure 3 shows the nominal working area of the BES, the curve is calculated by modeling the lithium battery through Simulink's model and each BES is $14.25 \mathrm{kWh}$.

The reference voltage $V_{\mathrm{BES}}$ establishes the discharge curve of the BES within the nominal operating area. Figure 4 shows the operation limits considering three levels: normal, low and high-level SoC.

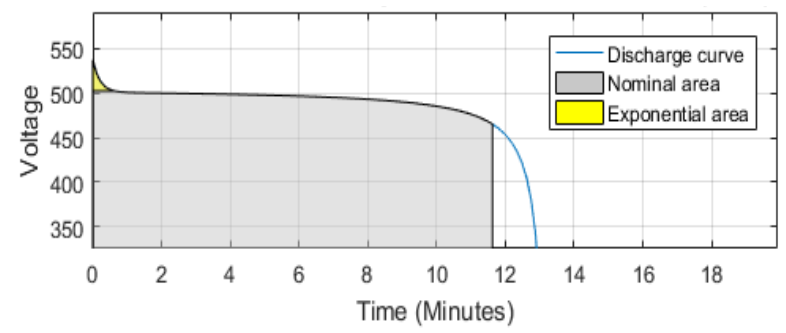

Figure 3. SoC determination with discharge voltage at $5 \mathrm{C}$ and $135 \mathrm{~A}$

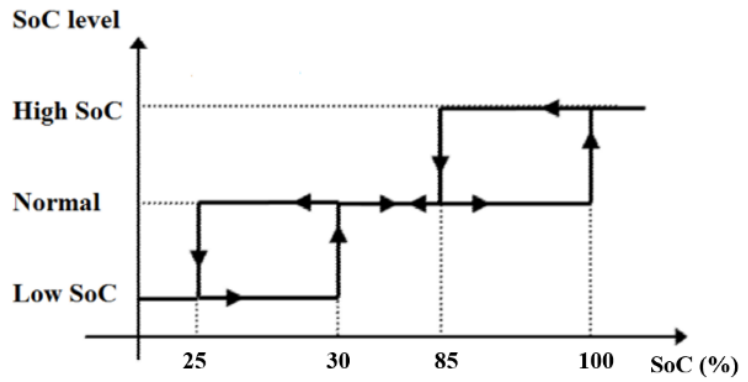

Figure 4. SoC level determination through the VBES

Figure 5 represents the dynamic control system used between BES and EV. In order to maintain a constant voltage on the $\mathrm{EV}$ side, the measured voltage $\mathrm{V}_{\mathrm{BES}}$ is compared at the end with a reference voltage $V_{R E F}$. $V_{R E F}$ is used as a linear loop of the $\mathrm{DC} / \mathrm{DC}$ converter for the dynamic limitation of the BES current and to determine the end of the SoC levels.

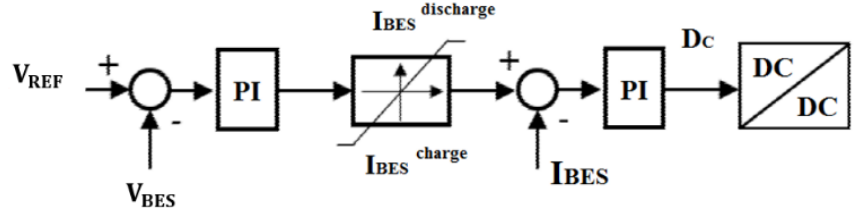

Figure 5. BES control system

The PI controller uses the $\mathrm{I}_{\mathrm{BES}}$ as a current reference of the BES to control the transferred power through EV. The $\mathrm{I}_{\mathrm{BES}}$ is limited in function to the discharging rate $5 \mathrm{C}$. The PI controls the duty cycle of the BES DC/DC converter within the set parameters. When the $\mathrm{SOC}_{\mathrm{BES}}$ reaches $25 \%$ the BES will stop to transfer power to the vehicle. The $\mathrm{AC} / \mathrm{DC}$ converter will recharge each BES with $50 \mathrm{~kW}$ and a charging rate of $4.62 \mathrm{C}$.

\section{Simulation Results and Case Study}

The reliability of the system and the performance of the DCFCS are evaluated by a 15-minute simulation in Matlab/ Simulink. A boost converter controls the DC/DC converter through the PI controllers. The boost converter helps to keep the voltage limits constant to ensure the stability of the system for each SoC of the EVs. Finally, in order to evaluate the stability of the converter, a case study has been done with an $\mathrm{EV}$ of $20 \mathrm{kWh}$ and $\mathrm{SoC}$ of $25 \%$. In addition, other studies have been performed considering the capability of the DCFCS in various scenarios with different EVs and SoCs.

\section{A. The charging process of an EV}

Every EV has a nominal capacity given by the manufacturers that represents an amount of kilometers that the car can reach with specific driving conditions. According to the tests performed in the EV laboratory, only $90 \%$ of the nominal capacity is used as work capacity. The remaining $10 \%$ will be used over time in proportion to the battery degradation. This system helps the user to maintain a consistent number of kilometers during their use of the EV. Therefore, for a typical $20 \mathrm{kWh}$ battery declared by the manufacturer, only $18 \mathrm{kWh}$ is used as work capacity.

The charger is able to transfer $11.4 \mathrm{kWh}$ with a discharging rate of $5 \mathrm{C}$. Considering the case study of an EV with $20 \mathrm{kWh}$ and a $\mathrm{SoC}$ of $25 \%, 18 \mathrm{kWh}$ could be usable to recharge (9)(10).

$$
\mathrm{EV}_{25 \% \mathrm{SoC}}=18 \cdot 0.25=4.5 \mathrm{kWh}
$$

$$
\mathrm{EV}_{\text {charged }}=11.4+4.5=16 \mathrm{kWh} \text {, with a SoC of } 88 \%
$$

Thanks to the communication between the DCFCS and the $\mathrm{EV}$, and according to IEC 15118 the EV will send a message to the DC charger when it reaches $80 \%$ of the SoC. The power delivered from the BES, in this case, will be $10 \mathrm{kWh}$, enough to reach $80 \% \mathrm{EV}_{\text {SoC }}$ in 10 -minutes.

The graphs in Figure 6 and Figure 7 show the discharging process of the BES1 through the EV and the power absorbed by the electric vehicle. 


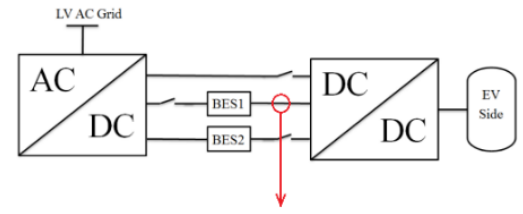

a)

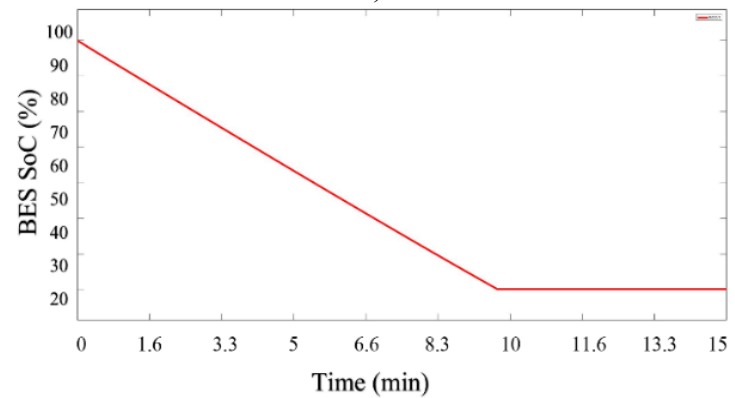

b)

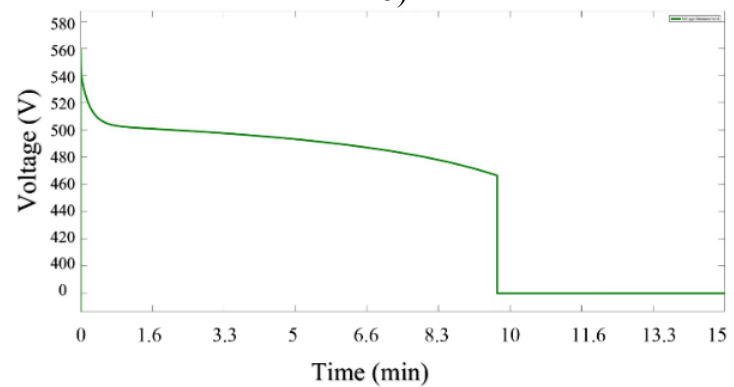

c)

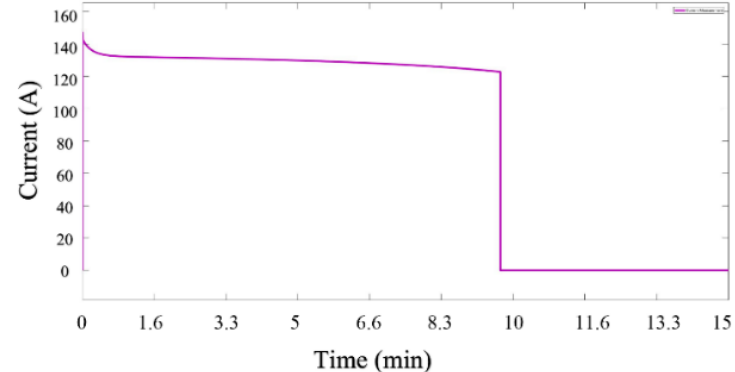

Figure $6 . \mathrm{BES}_{\mathrm{SoC} 1}$, discharging voltage at $5 \mathrm{C}$ and current delivered by the BES

As expected in Figure 6 (a) with decreasing of the $\mathrm{SoC}_{\mathrm{BES} 1}$ the voltage drops Figure 6 (b), and the current remains constant at $135 \mathrm{~A}$. Instead, Figure 7 represents the active power absorbed through the EV. The converter respects the power limit of $70 \mathrm{~kW}$ and discharging time at $5 \mathrm{C}$.

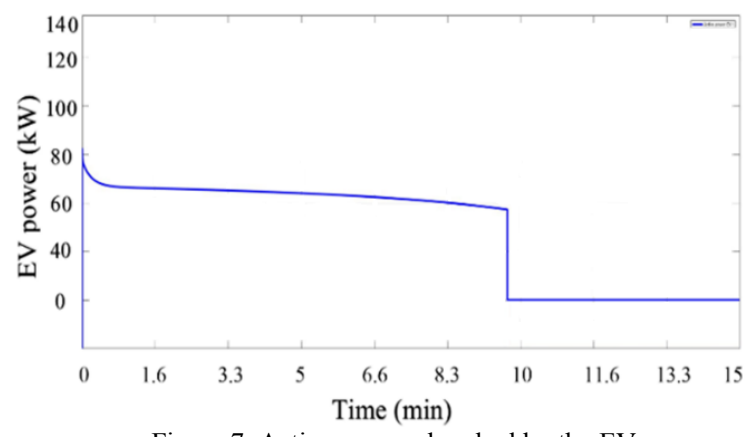

Figure 7. Active power absorbed by the EV

\section{B. Charging process of the BESs}

When the BES1 is charging an $\mathrm{EV}$ at $5 \mathrm{C}$, the $\mathrm{BES} 2$, if previously discharged, can be recharged through the grid with the $\mathrm{AC} / \mathrm{DC}$ converter at $50 \mathrm{~kW}$ and a charging rate of $4.63 \mathrm{C}$ as shown in Figure 8.
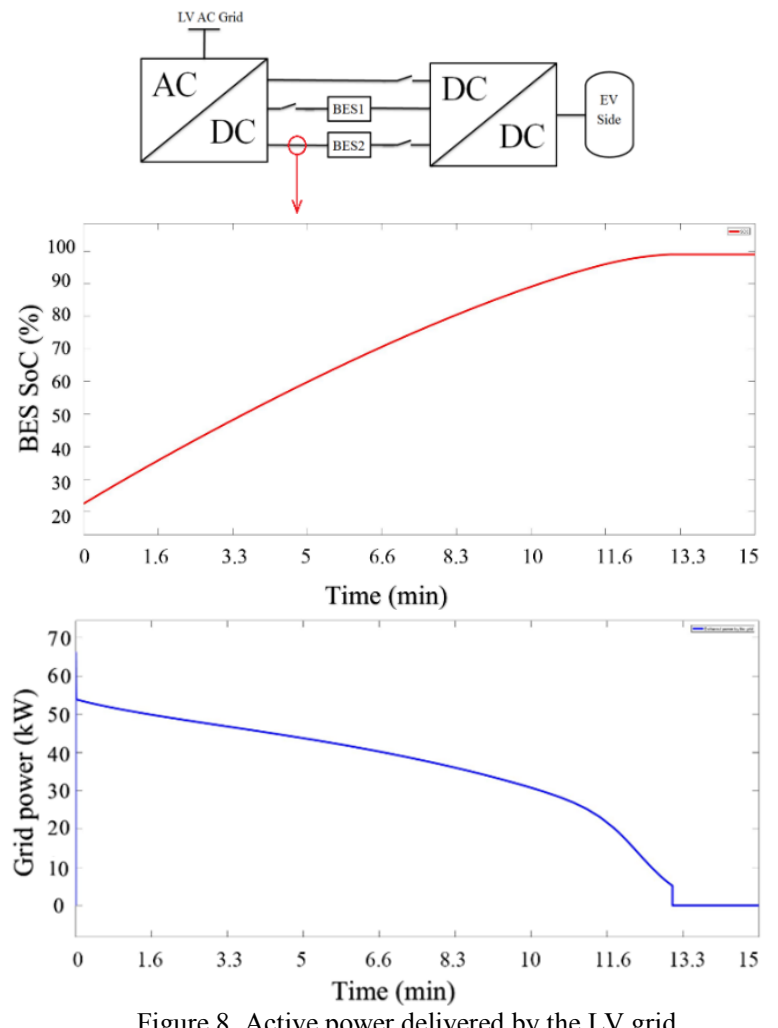

Figure 8. Active power delivered by the LV grid

The charging process of each BES will take more time to store $11.4 \mathrm{kWh}$. Each BES with 25\% SoC requires around 13 minutes because the grid power is limited to $50 \mathrm{~kW}$. As previously mentioned, the DCFCS has been designed to be used in LV grids, mainly in the cities. It can recharge each vehicle up to $80 \%$ of their SoC in a time period of between 10 minutes and 13 minutes, depending on the SoC of each EV.

\section{Different scenarios of the DCFCS}

The functionality of the charging system has been evaluated on a large scale by comparing different commercial EVs. The case studies take into account several models from 2015 to 2017 with battery pack between $16 \mathrm{kWh}$ and $60 \mathrm{kWh}$. As shown in table 2 below, all of the EVs have a nominal battery and a usable battery for the charging system. The calculations made are based on two scenarios:

1: $\mathrm{EVs}$ SoC at the beginning $=25 \%$, as shown in Figure 8

2: $\mathrm{EVs}$ SoC at the beginning $=35 \%$, as shown in Figure 9

All the EVs have been charged by the DCFCS with $70 \mathrm{~kW}$ through the BESs. The results associated with the capability of the DCFCS and its limits in order to supply energy to the end users are shown in Figure 8 and Figure 9. 
TABLE II. COMPARISOIN OF DIFFERENT COMMERCIAL EVS

\begin{tabular}{|c|c|c|c|}
\multicolumn{1}{c}{ Models (2015-2017) } & \multicolumn{1}{c}{ Range [km] } & \multicolumn{1}{c|}{ Battery [kWh] } & Usable battery [kWh] \\
\hline Mitsbuishi i-MiEV & 100 & 16 & 14.4 \\
\hline Smart Electric & 110 & 17 & 15.3 \\
\hline Chevy Spark EV & 130 & 20 & 18 \\
\hline BMW i3 & 130 & 22 & 19.8 \\
\hline Ford Focus EV & 130 & 23 & 20.7 \\
\hline Fiat 500e & 140 & 24 & 21.6 \\
\hline Nissan Leaf 24kWh & 130 & 24 & 21.6 \\
\hline Nissan Leaf 30kWh & 165 & 30 & 27 \\
\hline Kia Soul EV & 150 & 30 & 27 \\
\hline Mercedes B-Class ED & 170 & 36 & 32.4 \\
\hline eGolf & 300 & 37 & 33.3 \\
\hline Tesla S60 & 340 & 60 & 54 \\
\hline Tesla model 3 & 350 & 60 & 54 \\
\hline
\end{tabular}

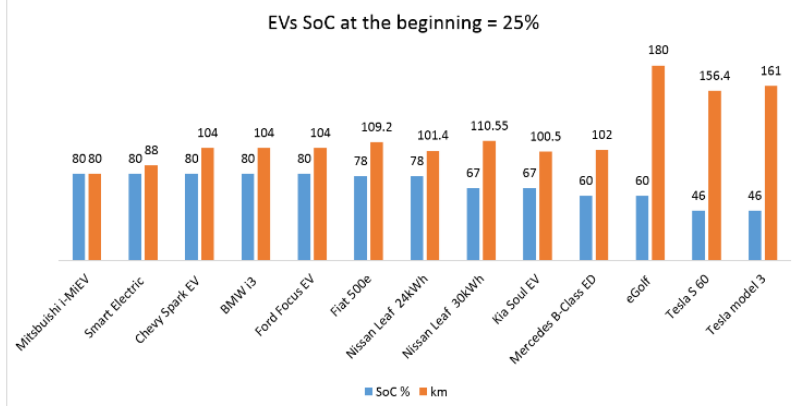

Figure 8 . EVs SoC and $\mathrm{km}$ available at the end of the charging process with SoC $25 \%$

EVs SoC at the beginning $=35 \%$

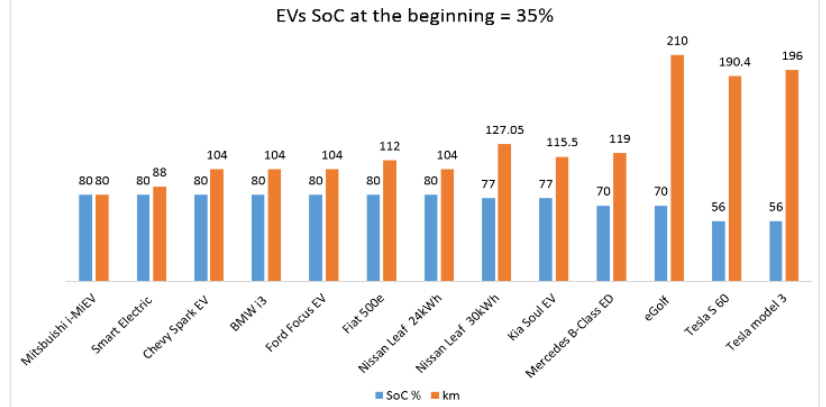

Figure 9. EVs SoC and $\mathrm{km}$ available at the end of the charging process with SoC $35 \%$

Figure 10 represents the charging limit of the DCFCS and the capability to recharge EVs up to $80 \%$ SoC according to the $\mathrm{EV}_{\mathrm{SoC}}$ and the battery pack.

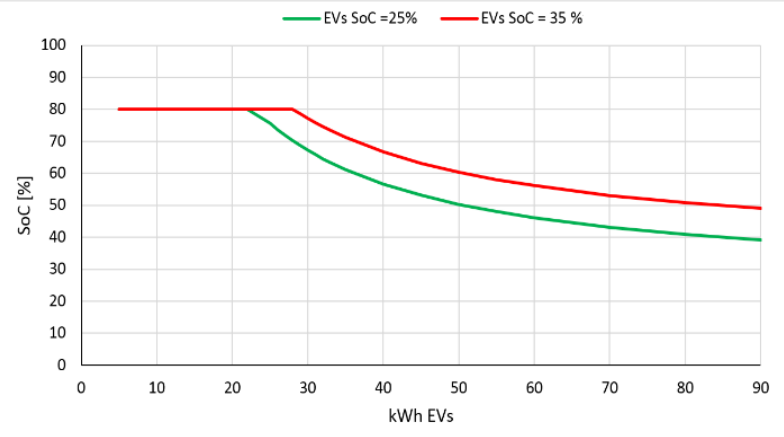

Figure 10. Charging limit of the DCFCS with EVs at $25 \% \mathrm{SoC}$ and $35 \% \mathrm{SoC}$

\section{CONCLUSIONS}

The paper introduced the configuration and an optimal design of BESs within fast charging stations. The results have shown that the DCFCS could be partly decoupled from the LV grid with the advantage of minimizing the grid impact and the congestion during the peak power demand significantly. By using the BES, the charging station can satisfy the following main conclusions:

1. The EV market will grow along with the impact on the electrical grid. The DCFCS keeps constant the charging power during peak demand.

2. The use of the intermediate battery helps to downsize the required capacity in $\mathrm{LV}$ grid.

3 . The DCFCS provides the possibility of more than $100 \mathrm{~km}$ driving in less than 10 minutes.

4. The optimal size of the BESs within charging stations is a trade-off between the grid constraints and their charging times. To conclude, an optimal control of the DC/DC converter was implemented, which could dynamically estimate the $\mathrm{SoC}$ of the BES. Thanks to a coordinated control strategy, the charging/discharging process could be automatically updated. As a future consideration, we will propose a fast charging station with BES, capable of recharging a large number of EVs in LV grids by adding load control flexibility.

\section{REFERENCES}

[1] Nordhavn project; Design - dimensioning of the energy infrastructure of future sustainable cities, http://www.energylabnordhavn.dk/

[2] Björn Nykvist1 and Måns Nilsson, "Rapidly falling costs of battery packs for electric vehicles", DOI: 10.1038/NCLIMATE2564, 2015.

[3] Wen Chen and Chunlin Guo, "The Impact of fast charging for EVs on Distribution System", ISSN: 1662-8985, vols. 1070, pp 1664-1667

[4] IEC 61851: Conductive charging system / DC EV charging station

[5] Yu Zheng, Zhao YangDong, YanXu, "Electric Vehicle Battery Charging/Swap Stations in Distribution Systems: Comparison Study and Optimal Planning" IEEE International, pp, vol. 29, no. 1, Jan 2014.

[6] S. Martinenas, A. B. Pedersen, M. Marinelli, P. B. Andersen, C. Træholt, "Electric Vehicle Smart Charging using Dynamic Price Signal" IEVC, 2014 IEEE International, pp.1-5, Florence, 17 Dec. 2014.

[7] Sanzhong Bai and Srdjan M. Lukic," Unified Active Filter and Energy Storage System for an MW Electric Vehicle Charging Station", " IEEE International, pp, vol. 28, no. 12, December 2013

[8] IEC 15118: Vehicle to grid communication interface

[9] IEC 62196: Connectors for conductive charging of electric vehicles

[10] K. Clement-Nyns, E. Haesen, and J. Driesen, "The impact of vehicle-togrid on the distribution grid," Electric Power Systems Research, vol. 81, no. 1, pp. 185-192, Jan. 2011.

[11] J. Hu, S. You, M. Lind, and J. Østergaard, "Coordinated charging of electric vehicles for congestion prevention in the distribution grid," Smart Grid, IEEE Transactions on, vol. 5, no. 2, pp. 703, March 2014

[12] K. Knezović, M. Marinelli, P. B. Andersen, C. Træholt, "Concurrent Provision of Frequency Regulation and Overvoltage Support by Electric Vehicles in a Real Danish Low Voltage Network," (IEVC), 2014 IEEE International, pp.1-5, Florence, 17- 19 Dec. 2014.

[13] W. Kempton and J. Tomić, "Vehicle-to-grid power implementation: From stabilizing the grid to supporting large-scale renewable energy," Journal on Power Sources, vol. 144, pp. 280-294, 2005.

[14] Battery Storage for Renewables: market Status and Technology Outlook," IRENA, Janary, 2015.

[15] Johan S. Vardakas, "Electric Vehicles Charging Management in Communication Controlled Fast Charging Stations" funded by EC FP7/2007-2013, under grant agreement No. 285969 [CODELANCE].

[16] IEC61850 Communication/automation, Part 90-8: Object model for EV

[17] GS Yuasa products, http://www.gsyuasa-lp.com/products.ht 